\title{
Studi Perubahan Unsur Kalium Akibat Pemupukan dan Pengaruhnya terhadap Hasil Tanaman
}

\section{Oviyanti Mulyani ${ }^{1}$, E. Hidayat Salim ${ }^{1}$, Anni Yuniarti, Yuliati Machfud, Apong Sandrawati ${ }^{1}$, dan Marisa Puspita Dewi²}

${ }^{1}$ Staff Pengajar Departemen Ilmu Tanah dan Sumberdaya Lahan Fakultas Pertanian Universitas Padjadjaran

${ }^{2}$ Alumni Program Studi Agroteknologi, Fakultas Pertanian Universitas Padjadjaran

Jl. Raya Bandung Sumedang Km 21 Jatinangor

Korespondensi: oviyanti.mulyani@unpad.ac.id; oviyanti@gmail.com

\begin{abstract}
Balanced fertilization is one solution to support sustainable agriculture. This experiment was conducted to determine the study of potassium caused by balanced fertilization. The experimental method used a Randomized Block Design (RBD) single factor with ten treatments and three replications, so the total is 30 experimental plots. The ten treatments consisted of : without fertilizer (0), 1/2, 1, 1,5 and 2 doses of organic fertilizer + without fertilizer (0), 1/4, 1/2, 3/4 and 1 doses of anorganic fertilizer. The results of this experiments showed that there were significant effects on potencial $K$, exchangeable $K, K$ uptake and yield of pakchoy from combination of organic fertilizer with anorganic fertilizer. The treatment 11/2 dose of organic fertilizer +1 dose of anorganic fertilizer produce the highest yield of pakchoy with $5.13 \mathrm{~kg} \mathrm{plot}^{-1}$ (increase $100 \%$ than control).
\end{abstract}

Keywords: Azolla pinnata compost, litter, peat, solid biofertilizer

\section{PENDAHULUAN}

Proses pemupukan merupakan salah satu usaha di dalam memenuhi kebutuhan nutrisi tanaman selama masa pertumbuhan. Saat ini, sistem pertanian di Indonesia sudah mulai mengarah kepada sistem pertanian ramah lingkungan. Sistem ini mengacu kepada penggunaan bahan-bahan tambahan yang diberikan ke dalam tanah yang tidak mengakibatkan residu. Salah satunya adalah penggunaan pupuk organik. Di lain pihak, untuk mencapai produksi hasil yang optimal, penggunaan pupuk organik saja tidak cukup. Penggunaan pupuk anorganik tetap diperlukan, namun penggunaannya harus diimbangi dengan aplikasi pupuk organik sehingga menghasilkan pemupukan berimbang.

Penggunaan pupuk ini diperlukan terutama untuk tanah-tanah yang kurang subur. Inceptisol merupakan jenis tanah yang penyebarannya terluas $\pm 70,52 \%$ dari luas daratan di Indonesia sehingga mempunyai potensi yang cukup besar untuk dikembangkan menjadi lahan pertanian. DI Jawa Barat Inceptisol mencapai luasan \pm 2.119 juta hektar (Subagyo dkk., 2000). Salah satu daerah penyebarannya di Jawa Barat terdapat di Jatinangor dan termasuk ke dalam sub ordo Udept, great group Eutrudepts (Arifin, 1994). Akan tetapi jenis tanah ini memiliki kendala diantaranya adalah $\mathrm{pH}$ tanahnya agak masam, kadar C-organik sedang, Kpotesial, dab K-dd rendah. Perlakuan tambahan diperlukan untuk meningkatkan daya dukung tanah sebagai media tanam.

Pemberian pupuk organik ke dalam tanah dapat memperbaiki sifat fisik, sifat kimia seperti menaikkan $\mathrm{pH}$ tanah, meningkatkan KTK, sebagai sumber hara makro dan mikro, meningkatkan aktivitas mikroba tanah serta ramah lingkungan, tidak mudah tercuci atau terangkut dari tanah, akan tetapi tetap dibutuhkan tambahan anorganik untuk penyerapan unsur hara yang cepat tersedia bagi tanaman (Kariada dkk, 2003; Suyono, 2008). Penggunaan pupuk organik yang tepat dapat mengurangi dosis pupuk buatan hingga $50 \%$ dari kebutuhan tanaman untuk meningkatkan kualitas lahan (Hakim dkk., 1986; Suriadikarta dan Simanungkalit, 2006). 
Kadar kalium pada Fluventic Eutrudepts rendah karena didominasi oleh kandungan liat yang relatif tinggi sehingga fiksasi $\mathrm{K}$ sangat kuat yang mengakibatkan konsentrasi $\mathrm{K}$ pada larutan tanah berkurang. Untuk produksi tanaman yang terpenting adalah konsentrasi $\mathrm{K}$ dalam tanah dapat dipertahankan pada tingkat yang memuaskan selama musim tanam (Ismunadji, 1989). Sehingga pemberian unsur $\mathrm{K}$ diharapkan mampu mensuplai kebutuhan unsur hara tanaman. Kemampuan tanah untuk menyediakan kalium dapat diketahui dari susunan mineral yang terdapat dalam tanah. Namun, umumnya mineral leusit dan biotit yang merupakan sumber langsung dalam kalium bagi tanaman (Soepardi, 1983).

Nurdiansah (2007) menyatakan bahwa pada Typic Eutrudepts, pemberian pupuk anorganik (225 kg pupuk majemuk, $110 \mathrm{~kg}$ Urea, $50 \mathrm{~kg}$ SP-36, $87 \mathrm{~kg} \mathrm{KCl}$ ) dapat meningkatkan K-dd sebesar $0,318 \mathrm{cmol} / \mathrm{kg}$ dan meningkatkan serapan-K sebesar 46,455 $\mathrm{mg} /$ tanaman. Penambahan pupuk K diharapkan dapat meningkatkan K-dd dan serapan-K pada tanaman pakchoy. Sedangkan menurut Sutriadi (2007), pemberian pupuk organik sebanyak 1 dosis yang dikombinasikan dengan pupuk NPK sebanyak $3 / 4$ dosis $(225 \mathrm{~kg}$ urea, $75 \mathrm{~kg}$ ZA, $75 \mathrm{~kg} \mathrm{SP-36,} \mathrm{dan} 75 \mathrm{~kg} \mathrm{KCl} \mathrm{ha-}$ 1) efektif meningkatkan pertumbuhan dan hasil caisim hingga 4,4\%. Sehingga dapat dilihat bahwa peranan aplikasi pupuk berimbang dapat mempengaruhi pola perubahan unsur kalium di dalam tanah.

\section{METODE PENELITIAN}

Percobaan ini dilaksanakan pada Fluventic Eutrudepts di Kebun Percobaan Pengelolaan Tanah dan Air, Fakultas Pertanian Universitas Padjadjaran. Tipe curah hujan menurut Schmidt dan Fergusson, termasuk tipe curah hujan $\mathrm{C}$ dengan rata-rata $2452 \mathrm{~mm} /$ tahun.

Bahan-bahan yang digunakan dalam percobaan ini adalah pupuk organik padat curah (POPC) sebanyak 2.700 g; Pupuk Urea $(45 \% \mathrm{~N})$ sebanyak $130 \mathrm{~g}$, SP-36 (36\% $\left.\mathrm{P}_{2} \mathrm{O}_{5}\right)$ sebanyak $130 \mathrm{~g}$, dan $\mathrm{KCl}\left(60 \% \mathrm{~K}_{2} \mathrm{O}\right)$ sebanyak 97,5 g; benih tanaman pakchoy green (Brassica chinensis, L.), varietas Tosakan bersertifikat; insektisida; bahan kimia untuk analisis tanah dan tanaman.

Peralatan laboratorium untuk analisis tanah dan tanaman; peralatan pendukung lainnya: timbangan, garpu tanah, kored, sekop, cangkul, gunting/pisau, penggaris, alat penyiram, selang untuk penyiraman, dan alat tulis; dan paranet.

Percobaan ini menggunakan Rancangan Acak Kelompok (RAK) yang terdiri dari 10 dosis perlakuan dan 3 ulangan, sehingga seluruhnya berjumlah 30 petak percobaan. Perlakuan tersebut terdiri dari pupuk organik padat curah dengan pupuk NPK. Perlakuan terdiri dari kombinasi pupuk organik pada granul dengan merk dagang "Boca Plus" dan pupuk NPK. Acuan dosis pupuk (1 kali dosis) untuk Boca Plus adalah rekomendasi dari produk, sedangkan dosis NPK sesuai dengan dosis Deptan. Kombinasi perlakuan tersebut dapat disusun sebagai berikut:

A. Kontrol

B. 0 Boca-Plus + NPK 1 kali dosis anjuran

C. 1 Boca-Plus +0 NPK

D. $1 / 2$ Boca-Plus + NPK 1 kali dosis anjuran

E. 1 Boca-Plus + NPK $1 / 4$ kali dosis anjuran

F. 1 Boca-Plus + NPK $1 / 2$ kali dosis anjuran

G. 1 Boca-Plus + NPK $3 / 4$ kali dosis anjuran

H. 1 Boca-Plus + NPK 1 kali dosis anjuran

I. 11/2 Boca-Plus + NPK 1 kali dosis anjuran

J. 2 Boca-Plus + NPK 1 kali dosis anjuran

\section{HASIL DAN PEMBAHASAN}

\subsection{Analisis Awal}

\subsubsection{Tanah}

Hasil analisis tanah awal menunjukkan bahwa tanah ini memiliki tekstur liat. Reaksi tanah ini termasuk agak masam dengan kandungan N-total, K-Potensial, dan K-dd rendah, serta P-potensial, KTK, kejenuhan basa sedang dan kejenuhan $\mathrm{Al}$ sangat rendah Berdasarkan uraian karakteristik sifat tanah 
di atas, maka dapat disimpulkan bahwa Fluventic Eutrudepts yang digunakan dalam penelitian ini memiliki beberapa kendala, hal ini dapat dilihat dari ketersediaan unsur $\mathrm{N}, \mathrm{P}$ dan $\mathrm{K}$ rendah sampai sedang, reaksi tanah agak masam dan memiliki kandungan liat yang tinggi (56\%). Kandungan liat yang tinggi perlu pemberian bahan organik, agar konsistensi dan strukturnya remah, aerasi baik, KTK tinggi dan tercukupi ketersediaan unsur haranya.

\subsubsection{Pupuk Organik Padat Curah}

Hasil analisis kandungan hara pupuk organik padat curah menunjukkan kandungan hara makro $\mathrm{N}$-Total sebesar 1,15\%, $\mathrm{P}_{2} \mathrm{O}$ $(1,83 \%), \mathrm{K}_{2} \mathrm{O}(2,02 \%)$ dan hara mikro $\mathrm{Fe}$ (6995,931 ppm), Zn (81,08 ppm). Kandungan unsur hara makro dan mikro dalam POPC ini diharapkan mampu meningkatkan kandungan unsur hara N,P, dan K. Aplikasi POPC juga diharapkan mampu meningkatkan efisiensi penggunaan pupuk anorganik terutama untuk pupuk NPK. Pupuk organik ini juga tidak mengandung bakteri E. coli dan Salmonella sp. yang dapat menginfeksi tubuh manusia karena proses pembuatannya dipanaskan sampai dengan suhu $70^{\circ} \mathrm{C}$. Kelebihan lain dari pupuk organik plus ini adalah mengandung Corganik yang tinggi $(20,61 \%)$.

\subsection{Komponen Pertumbuhan}

Komponen pertumbuhan yang diamati pada tanaman pakchoy terdiri dari tinggi tanaman, diameter tajuk dan jumlah daun yang diukur dari 7 hari setelah tanam (HST) sampai dengan $35 \mathrm{HST}$.

\subsubsection{Tinggi Tanaman}

Hasil pengamatan tinggi tanaman selama percobaan disajikan pada Gambar 1 di bawah ini. Pertumbuhan tinggi tanaman menunjukan rata-rata tanaman umur 14 HST tanaman pakchoy mengalami perkembangan tinggi yang relatif sama kecuali pada perlakuan kontrol.

Perbedaan rata-rata tinggi tanaman mulai terjadi pada umur $21 \mathrm{HST}$, perlakuan (2 POPC +1 NPK) menghasilkan tanaman tertinggi. Perlakuan dosis NPK di bawah dosis anjuran menunjukkan tinggi yang lebih rendah dari pada dosis anjuran 1 NPK. Terdapat kecenderungan bahwa peningkatan dosis POPC dan NPK akan meningkatkan tinggi tanaman.

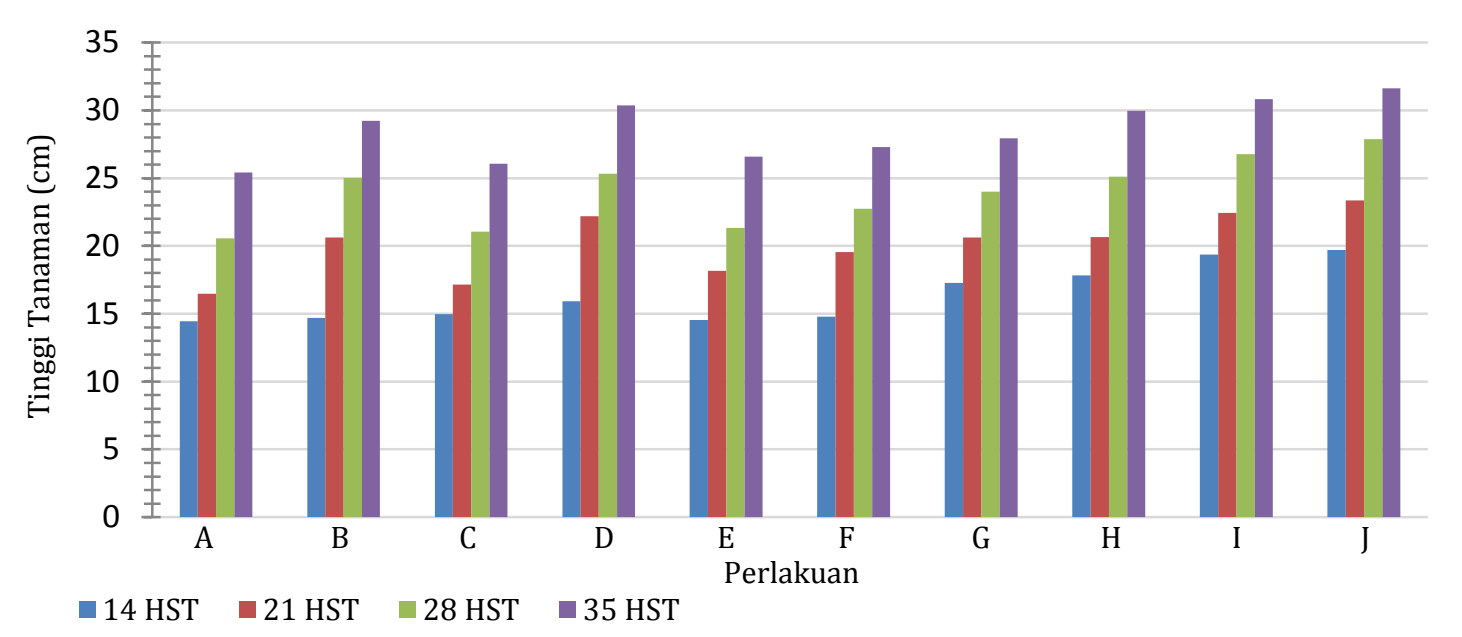

Gambar 1 Diagram pertumbuhan tinggi tanaman pakchoy pada berbagai perlakuan

\subsubsection{Jumlah Daun}

Hasil pengamatan terhadap jumlah daun disajikan pada Gambar 3. Pemberian pupuk NPK di bawah dosis anjuran (1 NPK) menghasilkan jumlah daun yang lebih sedikit dibandingkan dengan pemberian dosis NPK sesuai anjuran (1 NPK). Secara keseluruhan peningkatan dosis POPC dengan NPK dari dosis anjuran mampu meningkatkan jumlah daun tanaman pakchoy. 


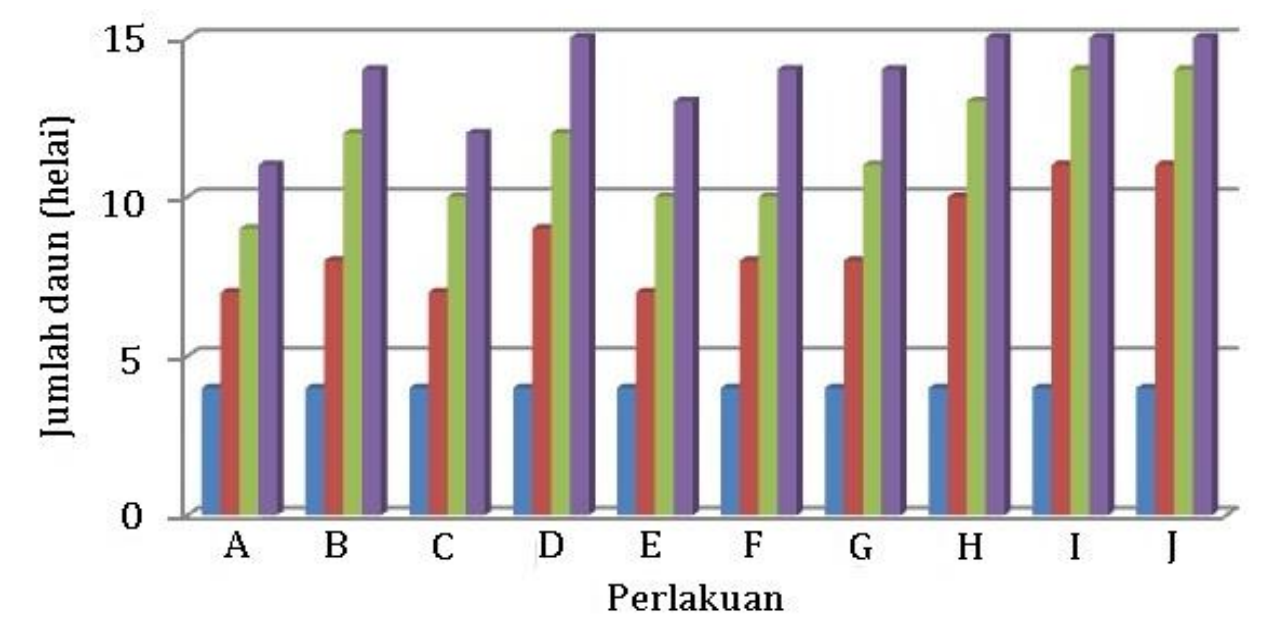

$=14 \mathrm{HST}=21 \mathrm{HST}=28 \mathrm{HST}=35 \mathrm{HST}$

Gambar 2 Diagram jumlah daun tanaman pada berbagai perlakuan

\subsubsection{Diameter Tajuk}

Hasil pengamatan diameter tajuk disajikan pada Gambar 3. Pada 14 HST perlakuan kontrol (A) memiliki diameter tajuk yang paling rendah. Pertumbuhan diameter tajuk pada umur 14 HST menunjukkan lebar yang bervariasi antar perlakuan. Diameter tajuk cenderung meningkat berbanding lurus dengan pemberian dosis pupuk NPK, dimana dosis NPK anjuran akan lebih baik dibandingkan dosis NPK dibawah anjuran. Pemberian dosis anjuran pupuk organik dengan dosis anjuran NPK berpotensi memberikan hasil tertinggi, yaitu $32,367 \mathrm{~cm}$ dengan peningkatan hasil sebesar 22,6\% dibanding control.

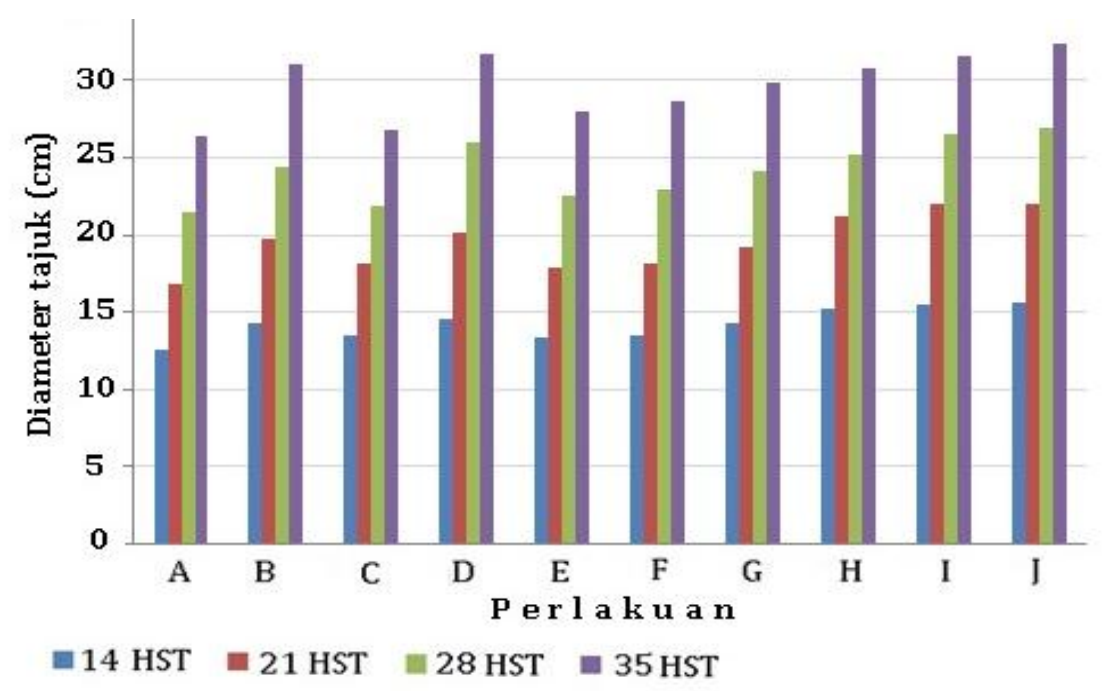

Gambar 3 Diagram pertumbuhan diameter tajuk pada berbagai perlakuan

\subsection{Komponen Hasil Tanaman}

Berdasarkan hasil uji statistik pengaruh pemberian kombinasi dosis pupuk organik dengan pupuk NPK menunjukkan peningkatan hasil tanaman pakchoy terhadap kontrol tetapi tidak berbeda nyata terhadap tiap perlakuan Tabel.6 di bawah ini. Perlakuan dengan 1 dosis POPC dan tanpa
NPK tidak menghasilkan hasil yang tinggi, karena unsur hara dari POPC bersifat lambat tersedia sehingga dapat menghambat pertumbuhan tanaman.

Berdasarkan Tabel 1, kombinasi POPC dan pupuk NPK dapat meningkatkan hasil per satuan luas. Pupuk organik berfungsi sebagai penyedia unsur hara bagi tanaman yang dapat 
memobilisasi nutrisi yang tidak larut menjadi tersedia. Pupuk organik juga berpengaruh baik langsung maupun tidak langsung terhadao pertumbuhan dan perkembangan tanaman (Suriadikarta dan Simanungkalit, 2006). Penggunaan pupuk organik juga dapat mengurangi dosis pupuk anorganik, dalam hal ini NPK. Pengurangan terhadap dosis pupuk anorganik akan meningkatkan efiisiensi pemupukan dan dampak negatif akibat pemupukan seperti pencemaran (Soepardi, 1983).

Tabel 1 Pengaruh kombinasi pupuk organik dengan pupuk NPK terhadap hasil tanaman pakchoy

\begin{tabular}{lcc}
\hline \multirow{2}{*}{ Perlakuan } & \multicolumn{2}{c}{ Hasil Tanaman } \\
\cline { 2 - 3 } & $\mathrm{Kg} /$ petak & ton/ha \\
\hline $\mathrm{A}$ = Kontrol & $2,30 \mathrm{a}$ & 9,77 \\
$\mathrm{~B}=$ 0 Boca Plus + 1 NPK & $3,45 \mathrm{c}$ & 14,66 \\
$\mathrm{C}=1$ Boca Plus + 0 NPK & $2,40 \mathrm{a}$ & 10,20 \\
$\mathrm{D}=1 / 2$ Boca Plus + 1 NPK & $4,10 \mathrm{c}$ & 17,42 \\
$\mathrm{E}=1$ Boca Plus + 1/4 NPK & $2,55 \mathrm{ab}$ & 10,84 \\
$\mathrm{~F}=1$ Boca Plus + 1/2 NPK & $2,77 \mathrm{~b}$ & 11,77 \\
$\mathrm{G}=1$ Boca Plus + 3/4 NPK & $3,73 \mathrm{c}$ & 15,85 \\
$\mathrm{H}=1$ Boca Plus + 1 NPK & $4,47 \mathrm{~d}$ & 18,99 \\
$\mathrm{I}=11 / 2$ Boca Plus + 1 NPK & $4,87 \mathrm{e}$ & 20,70 \\
$\mathrm{~J}=$ = 2 Boca Plus + 1 NPK & 5,13 e & 21,80 \\
\hline
\end{tabular}

Keterangan : Angka-angka yang diikuti huruf yang sama tidak berbeda nyata menurut uji jarak berganda Duncan 5 \%.

\subsection{Kadar Kalium dalam Tanah}

\subsubsection{Kadar K-potensial}

Berdasarkan hasil uji statistik yang telah dilakukan, pemberian kombinasi pupuk organik padat curah dan pupuk NPK berpengaruh nyata terhadap kandungan $\mathrm{K}$ potensial tanah. Secara umum, setiap perlakuan mampu meningkatkan K-potensial tanah jika dibandingkan dengan kontrol (Tabel 2).

Peningkatan K-potensial ini belum tentu dapat menaikkan hasil produksi tanaman, hal ini diakibatkan karena K-potensial belum bisa langsung di gunakan tanaman. Nilai Kpotensial merupakan $\mathrm{K}$ tidak dapat dipertukarkan yang termasuk kedalam $\mathrm{K}$ lambat tersedia, walaupun kadar K-potensial tinggi, tetapi ketersediaan $\mathrm{K}$ bagi tanaman ( $\mathrm{K}$ aktual) sering menjadi masalah karena $\mathrm{K}$ difiksasi oleh mineral liat tipe 2:1, seperti dari golongan smektit dan vermikulit yang dominan di tanah tersebut (Douglas, 1989 dalam Suyono, 2008).

Tabel 2 Pengaruh kombinasi pupuk organik dengan pupuk NPK terhadap Kpotensial

\begin{tabular}{ll}
\hline \multicolumn{1}{c}{ Perlakuan } & $\begin{array}{c}\mathrm{K}_{2} \text { O Potensial } \\
(\mathrm{mg} \mathrm{100} \mathrm{g-1)}\end{array}$ \\
\hline $\mathrm{A}=$ Kontrol & $12,140 \mathrm{a}$ \\
$\mathrm{B}=0$ Boca-Plus + 1 NPK & $13,990 \mathrm{~b}$ \\
$\mathrm{C}=1$ Boca-Plus + 0 NPK & $12,517 \mathrm{a}$ \\
$\mathrm{D}=1 / 2$ Boca-Plus + 1 NPK & $14,807 \mathrm{c}$ \\
$\mathrm{E}=1$ Boca-Plus + 1/4 NPK & $14,470 \mathrm{bc}$ \\
$\mathrm{F}=1$ Boca-Plus + 1/2 NPK & $14,803 \mathrm{c}$ \\
$\mathrm{G}=1$ Boca-Plus + 3/4 NPK & $14,873 \mathrm{c}$ \\
$\mathrm{H}=1$ Boca-Plus + 1 NPK & $15,037 \mathrm{c}$ \\
$\mathrm{I}=11 / 2$ Boca-Plus + 1 NPK & $15,063 \mathrm{c}$ \\
$\mathrm{J}=2$ Boca-Plus + 1 NPK & $15,060 \mathrm{c}$ \\
\hline
\end{tabular}

Keterangan : Angka-angka yang diikuti huruf yang sama tidak berbeda nyata menurut uji jarak berganda Duncan 5 \%

Kalium tidak dapat dipertukarkan terdiri dari K-terfiksasi dan K-mineral. Walaupun pelepasan sangat lambat dan relatif tidak tersedia bagi tanaman namun tetap dinilai sebagai cadangan kalium tanah. K-tidak dapat dipertukarkan akan semakin meningkat jika tanah bereaksi sangat masam, banyaknya mineral liat terutama mineral liat tipe 2:1, jumlah $\mathrm{K}$ yang ditambahkan berlebihan (penambahan $\mathrm{K}$ cenderung meningkatkan fiksasi), pembasahan dan pengeringan tanah serta pembekuan dan pencairan (Leiwakabessy dan Sutandi, 2004).

\subsubsection{Kadar K dapat ditukar (K-dd)}

Hasil pengukuran K-dd pada setiap perlakuan dapat dilihat pada Tabel 3 . Pemberian kombinasi pupuk organik dengan pupuk NPK memberikan pengaruh terhadap $\mathrm{K}$ dapat dipertukarkan pada setiap perlakuan dibandingkan dengan kontrol. 
Tabel 3 Pengaruh kombinasi pupuk organik dengan pupuk NPK terhadap K-dd

\begin{tabular}{lc}
\hline \multicolumn{1}{c}{ Perlakuan } & $\begin{array}{c}\text { K-dd } \\
\text { (cmol/kg) }\end{array}$ \\
\hline $\mathrm{A}=$ Kontrol & $0,240 \mathrm{a}$ \\
$\mathrm{B}=0$ BOCA-PLUS + 1 NPK & $0,260 \mathrm{~b}$ \\
$\mathrm{C}=1$ BOCA-PLUS + 0 NPK & $0,243 \mathrm{a}$ \\
$\mathrm{D}=1 / 2$ BOCA-PLUS + 1 NPK & $0,270 \mathrm{~cd}$ \\
$\mathrm{E}=1$ BOCA-PLUS + 1/4 NPK & $0,261 \mathrm{~cd}$ \\
$\mathrm{~F}=1$ BOCA-PLUS + 1/2 NPK & $0,270 \mathrm{~cd}$ \\
$\mathrm{G}=1$ BOCA-PLUS + 3/4 NPK & $0,271 \mathrm{~cd}$ \\
$\mathrm{H}=1$ BOCA-PLUS + 1 NPK & $0,272 \mathrm{~d}$ \\
$\mathrm{I}=11 / 2$ BOCA-PLUS + 1 NPK & $0,276 \mathrm{~d}$ \\
$\mathrm{~J}=$ 2 BOCA-PLUS + 1 NPK & $0,275 \mathrm{~d}$ \\
\hline
\end{tabular}

Keterangan : Angka-angka yang diikuti huruf yang sama tidak berbeda nyata menurut uji jarak berganda Duncan 5 \%.

Pada perlakuan kontrol menunjukkan bahwa jumlah K-dd terkecil akibat tidak adanya pemberian pupuk dan tidak berbeda nyata dengan perlakuan yang hanya menggunakan 1 dosis Pupuk organik padat curah sehingga K-dd lambat tersedia bagi tanaman. Ketersediaan kalium yang terangkut oleh tanaman bisa mencapai tiga hingga empat kali dari pengangkutan $P$ dan jumlahnya dapat menyamai pengangkutan nitrogen (Soepardi, 1983). Kehilangan Kalium akibat diserap oleh tanaman pakchoy berpengaruh terhadap hasil tanaman pakchoy.

Kalium mempengaruhi perpanjangan akar, akar yang panjang akan meningkatkan unsur hara. Pemberian kombinasi dosis pupuk organik dengan pupuk NPK memberikan pengaruh terhadap $\mathrm{K}$ dapat dipertukarkan pada setiap perlakuan dibandingkan dengan kontrol. Hal ini karena pupuk organik dapat membantu meningkatkan kemampuan tanah menahan air, sehingga tanah tetap dalam keadaan lembab. Kelembaban ini mempengaruhi mekanisme pelepasan $\mathrm{K}$ yang terjerap oleh mineral liat tipe 2: 1 ke dalam larutan tanah menjadi bentuk tersedia. Selain itu, kalium yang berasal dari dekomposisi pupuk organik juga mempengaruhi peningkatan $\mathrm{K}$ tersedia tanah (Sudadi, 2007). Kadar K dalam larutan meningkat akibat pemberian pupuk, lalu $\mathrm{K}$ terjerap juga meningkat sehingga ketersediaannya untuk tanaman meningkat (Nursyamsi, 2006).

Berdasarkan model regresi pada Gambar 4, semakin meningkat K-potensial maka semakin meningkat K-dd. Berdasarkan persamaan regresi yang diperoleh, dimana nilai $\mathrm{R}^{2}=0.86$, hal ini menunjukkan bahwa 86\% peningkatan K-dd dipengaruhi oleh peningkatan K-potensial.

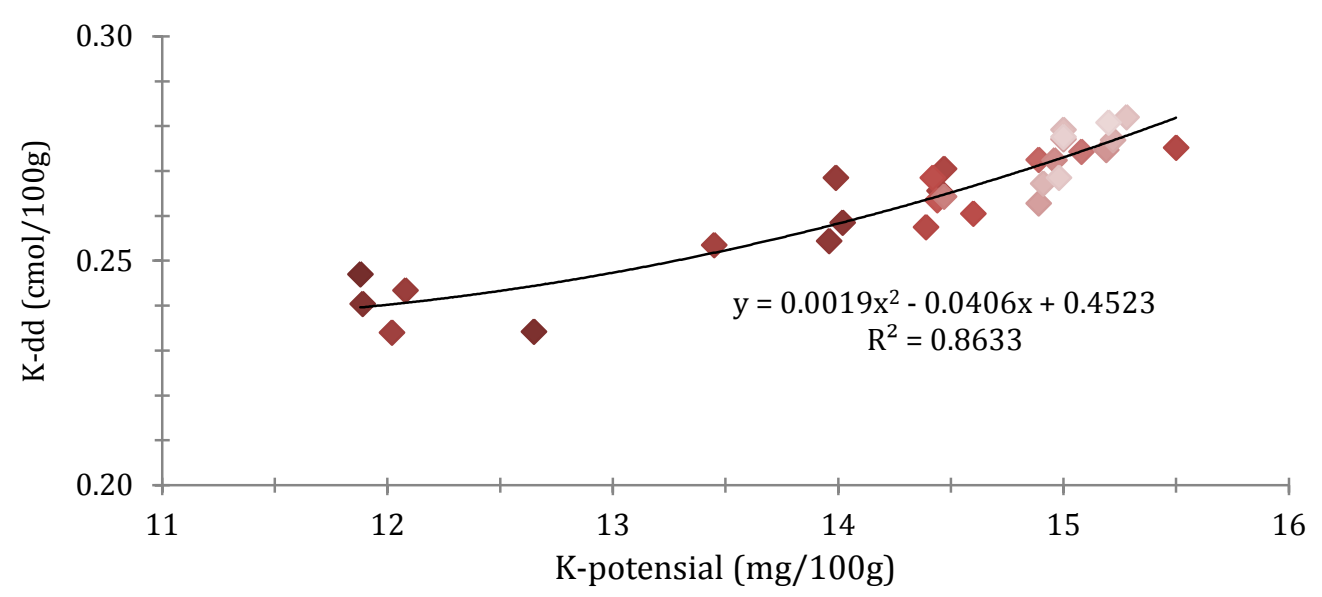

Gambar 4 Model regresi antara K-potensial dengan K-dd

Korelasi antar kedua parameter tersebut menunjukkan bahwa K-potensial dan K-dd, memiliki nilai hubungan (korelasi) yang kuat.
Hal ini diperkuat dengan pernyataan Soepartini dkk. (1994) bahwa kadar Kpotensial dalam tanah berkorelasi positif 
dengan kadar k-dd karena semakin tinggi kadar K-dd dalam tanah, maka semakin tinggi kadar K-potensialnya. Nilai K-dd di dalam tanah lapisan bawah sangat bervariasi, hal ini ditentukan oleh kadar liat dan konsistensi tanah.

\subsection{Serapan K}

Berdasarkan hasil uji statistik (Tabel 4) pengaruh pemberian kombinasi pupuk organik dan pupuk NPK tidak beda nyata diantara perlakuan tetapi berbeda nyata jika dibandingkan dengan kontrol.

Tabel 4 Pengaruh kombinasi pupuk organik dengan pupuk NPK terhadap serapan-K

\begin{tabular}{ll}
\hline \multicolumn{1}{c}{ Perlakuan } & \multicolumn{1}{c}{$\begin{array}{c}\text { Serapan-K } \\
(\%)\end{array}$} \\
\hline $\mathrm{A}=$ Kontrol & $1,15 \mathrm{ab}$ \\
$\mathrm{B}=0$ Boca-Plus + $1 \mathrm{NPK}$ & $1,20 \mathrm{~cd}$ \\
$\mathrm{C}=1$ Boca-Plus + 0 NPK & $1,12 \mathrm{a}$ \\
$\mathrm{D}=1 / 2$ Boca-Plus + 1 NPK & $1,23 \mathrm{de}$ \\
$\mathrm{E}=1$ Boca-Plus + $1 / 4 \mathrm{NPK}$ & $1,17 \mathrm{bc}$ \\
$\mathrm{F}=1$ Boca-Plus + $1 / 2 \mathrm{NPK}$ & $1,20 \mathrm{~d}$ \\
$\mathrm{G}=1$ Boca-Plus + 3/4 NPK & $1,21 \mathrm{de}$ \\
$\mathrm{H}=1$ Boca-Plus + $1 \mathrm{NPK}$ & $1,25 \mathrm{e}$ \\
$\mathrm{I}=11 \frac{1}{2}$ Boca-Plus + $1 \mathrm{NPK}$ & $1,22 \mathrm{de}$ \\
$\mathrm{J}=2$ Boca-Plus + $1 \mathrm{NPK}$ & $1,23 \mathrm{de}$ \\
\hline
\end{tabular}

Keterangan : Angka-angka yang diikuti huruf yang sama tidak berbeda nyata menurut uji jarak berganda Duncan $5 \%$.
Perlakuan 1 dosis POPC +1 dosis NPK menunjukkan hasil tertinggi serapan-K dibandingkan perlakuan lainnya. Hal ini diduga penggunaan pupuk $\mathrm{KCl}$ yang diberikan telah terdekomposisi dengan baik dan tersedia untuk tanaman. Serapan K oleh tanaman meningkat sejalan dengan peningkatan dosis pupuk NPK dan kombinasinya dengan POPC, sehingga setiap perlakuan memberikan pengaruh nyata terhadap kontrol.

Pemberian dosis pupuk NPK dan kombinasinya dengan POPC yang meningkat dapat meningkatkan serapan $\mathrm{K}$ secara nyata. Jumlah kalium yang diserap oleh tanaman ditentukan oleh beberapa konsentrasi kalium dalam larutan tanah, semakin tinggi konsentrasi kalium dalam tanah, maka semakin tinggi serapan kalium tanamannya (Darlison, 1988 dalam Suyono, 2008). Kombinasi pemberian POPC dengan NPK mampu menjaga ketersediaan $\mathrm{K}$ dalam tanah sehingga tanaman dapat tumbuh optimal.

Berdasarkan model regresi pada Gambar 5 , diperoleh persamaan $y=48.77 x^{2}-22.53 x+$ $3.741\left(\mathrm{R}^{2}=0,68\right)$. Hal ini menunjukkan bahwa nilai $\mathrm{K}$-dd dan serapan-K memiliki korelasi yang kuat, dimana $68 \%$ peningkatan serapan$\mathrm{K}$ dipengaruhi oleh K-dd. Penambahan pupuk $\mathrm{KCl}$ dan pupuk organik mampu meningkatkan kandungan K-potensial, proses dekomposisi dan minerali-sasi pada pupuk organik dan NPK mening-katkan K-dd dalam tanah.

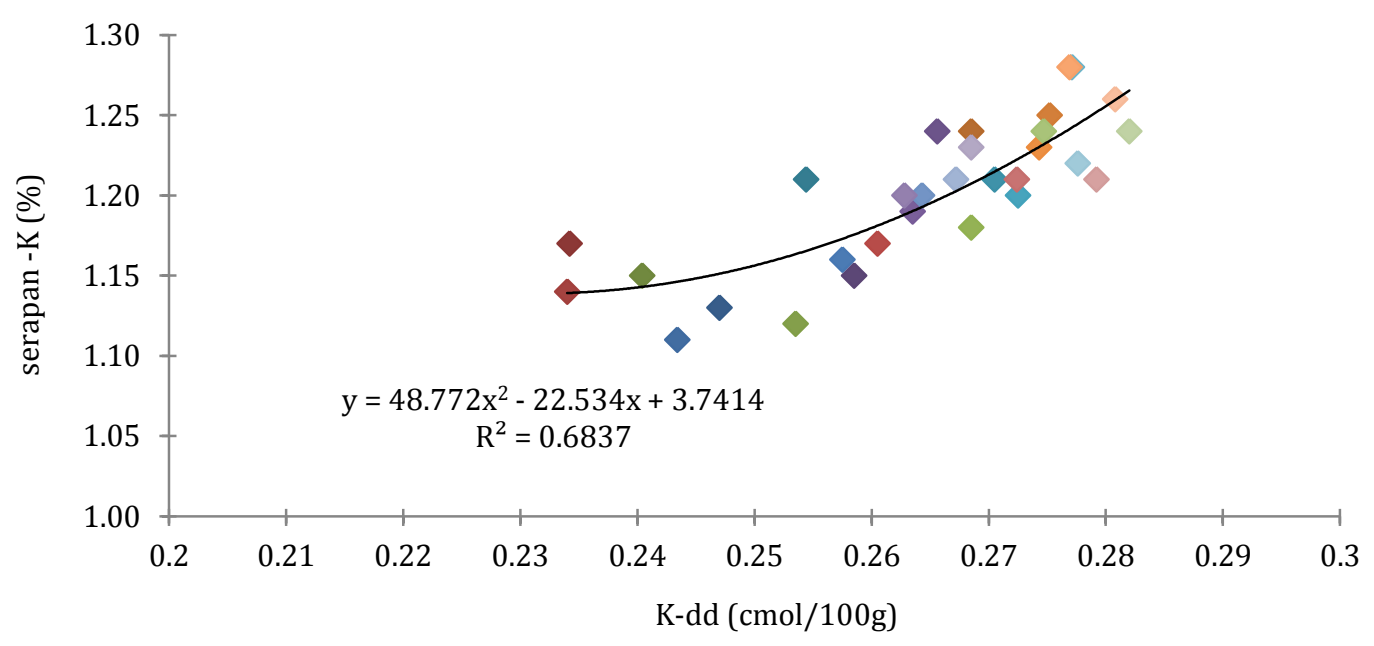

Gambar 5 Model regresi antara K-dd dengan serapan-K 
Nilai serapan $\mathrm{K}$ juga berpotensi berpengaruh kepada hasil tanaman pakchoy. Berdasarkan Gambar 6, persamaan regresi serapan-K adalah $\mathrm{y}=-9.482 \mathrm{x}^{2}+38.8 \mathrm{x}-29.35$ $\left(\mathrm{R}^{2}=0,52\right)$, angka tersebut menunjukkan bahwa $52 \%$ peningkatan hasil tanaman dipengaruhi oleh serapan-K. Secara umum, semakin meningkat serapan-K maka semakin meningkat hasil tanaman. Peningkatan Kpotensial dapat meningkatkan K-dd dalam tanah. Semakin besar K-dd, maka semakin besar serapan-K tanaman, sehingga tanaman dapat tumbuh dengan optimal.

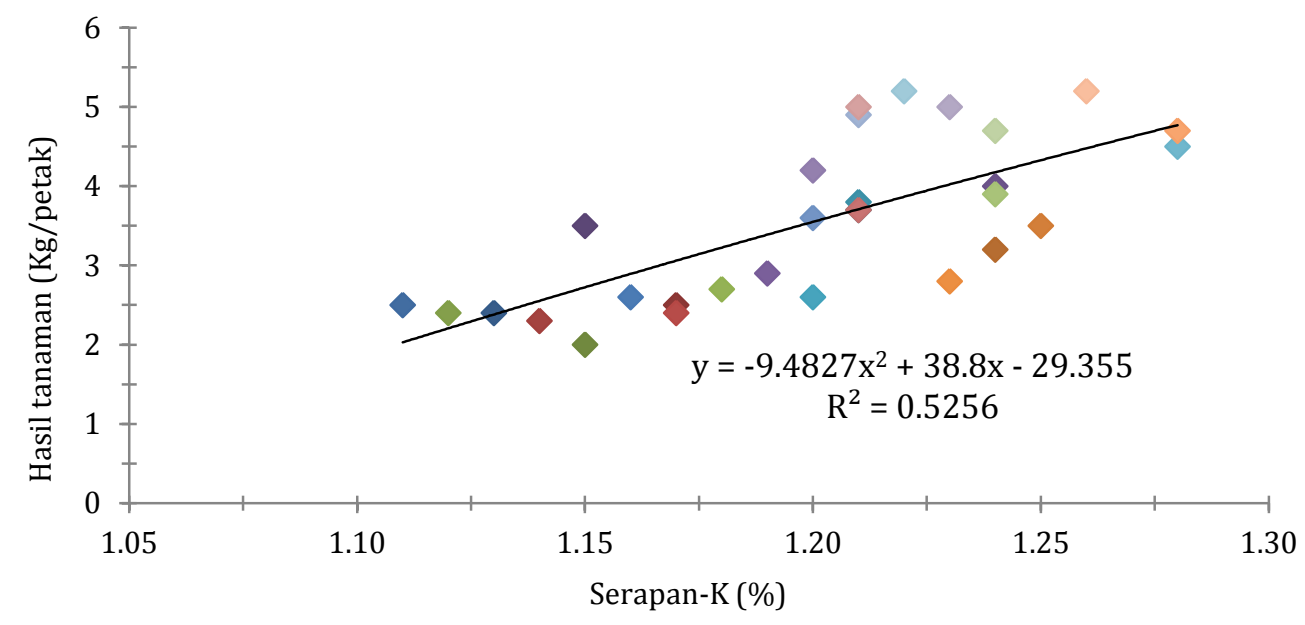

Gambar 6 Model Regresi antara Serapan-K dengan Hasil Tanaman

\section{KESIMPULAN}

Kombinasi dosis pupuk organik dengan pupuk NPK berpengaruh terhadap peningkatan K-potensial, K-dd, serapan-K serta hasil tanaman pakchoy. Perlakuan 11/2 dosis pupuk organik +1 dosis pupuk NPK menghasilkan bobot segar tanaman pakchoy tertinggi sebesar $5,13 \mathrm{~kg}^{\text {petak }}{ }^{-1}$ dengan peningkatan hasil tanaman pakchoy lebih dari 100\% dibanding kontrol

Nilai K-potensial berkorelasi tinggi dengan nilai K-dd. Nilai K-dd juga berkorelasi positif dengan serapan K. Nilai serapan $\mathrm{K}$ juga berkorelasi positif terhadap hasil tanaman pakhcoy.

\section{DAFTAR PUSTAKA}

Arifin, M. 1994. Pedogenesis Andisol Berbahan Induk Abu Volkan Andesit Dan Basalt Pada Beberapa Zona Agroklimat Di Daerah Perkebunan Teh Jawa Barat. Disertasi. Institut Pertanian Bogor. Bogor.
Hakim, N., N.Yusuf, G. Sutopo, D. Amin, Go Ban Hong dan Bailey. 1986. Dasar-dasar Ilmu Tanah. Universitas Lampung.

Ismunadji. 1989. Kalium: Kebutuhan dan Kegunaannya dalam Pertanian Modern. Balai Penelitian Tanaman Pangan Bogor. Penerbit Gaya Tehnik, Bogor. Hlm 64.

Leiwakabessy, F.M. dan Sutandi A 2004. Pupuk dan Pemupukan. Departemen Ilmu Tanah Fakultas Pertanian. Institut Pertanian Bogor. Diktat Kuliah.

Kariada, I.K., N.L. Kartini, dan I.B. Aribawa. 2003. Pengaruh pupuk organik kascing (POK) dan NPK terhadap sifat kimia tanah dan hasil kacang panjang di lahan kering Desa Pegok Kabupaten Bandung. Prosiding. Pemberdayaan Petani Miskin di Lahan Marginal Melalui Inovasi Tekonologi Tepat Guna. http:// ntb.litbang.deptan.go.id/ ind/2004/TPH/pengaruhpupuk.doc.

Nursyamsi, D. 2006. Kebutuhan Hara Kalium Tanaman Kedelai Di Tanah Ultisol. Balai Penelitian Tanah, Bogor. 
Soepardi, G. 1983. Sifat dan Ciri Tanah. Jurusan Ilmu Tanah Fakultas Pertanian IPB. Bogor.

Soepartini, M., Nurjana, A. Kasno, S. Ardjakusuma, S. Moersidi dan J.S. Adiningsih. 1994. Status Hara P dan K serta Sifat-sifat Tanah sebagai Penduga Kebutuhan Pupuk Padi Sawah di Pulau Lombok. Pemebritaan Pen. Tanah dan Pupuk 12: 23-35.

Subagyo. H, Suharta, dan B. Siswanto. 2000. Tanah-Tanah Pertanian di Indonesia. Pusat Penelitian Tanaman Pangan, Bogor

Sudadi, N.H. Yuni dan Sumani. 2007. Ketersediaan K dan hasil kedelai Glycine max L.. Merril pada tanah
Vertisol yang diberi mulsa dan pupuk kandang. Jurnal Ilmu Tanah dan Lingkungan. Vol. 7(1),h : 8-12.

Suriadikarta, D.A. dan R.D.M. Simanungkalit. 2006. Pupuk Organik dan PupukHayati. Balai Besar Litbang Sumberdaya Lahan Pertanian Badan Penelitian dan Pengembangan Pertanian, Bogor.

Sutriadi ,M.T. 2007. Pengaruh Pupuk Organik Cair Pada Pertumbuhan dan Hasil Caisim (Brassica Rapa Convar) di Inceptisols, Bogor. Online: http://balittanah.litbang.deptan.go.id/. pdf.(Diakses tanggal 28 Oktober 2011).

Suyono, A. D. 2008. Pupuk dan Pemupukan. Unpad Press. Bandung. 